\title{
Design of a Reed Bed System for Treatment of Domestic Wastewater using Native Plants
}

\author{
Fayeq Abdel Hafez Al-Ajalin', Mushrifah Idris ${ }^{1,2}$, Siti Rozaimah Sheikh Abdullah, \\ Setyo Budi Kurniawan ${ }^{3}$, Muhammad Fauzul Imron ${ }^{4 *}$
}

1 Faculty of Science and Technology, Universiti Kebangsaan Malaysia, 43600 UKM Bangi, Selangor, Malaysia

2 Tasik Chini Research Centre, Faculty of Science and Technology, Universiti Kebangsaan Malaysia, 43600 UKM Bangi, Selangor, Malaysia

3 Department of Chemical and Process Engineering, Faculty of Engineering and Built Environment, Universiti Kebangsaan Malaysia, 43600 UKM Bangi, Selangor, Malaysia

4 Study Program of Environmental Engineering, Department of Biology, Faculty of Science and Technology, Universitas Airlangga, Kampus C UNAIR, Jalan Mulyorejo, Surabaya 60115, Indonesia

* Corresponding author's e-mail: fauzul.01@gmail.com

\begin{abstract}
The reed bed system is one types of phytoremediation technology for removing pollutants from the environment. This technology provides an environmentally friendly approach to treating contamination with competitive cost, compared to the physico-chemical treatment. The design of reed bed system is highly important in order to achieve the highest pollutant removal efficiency. The design of reed bed system affects the natural oxygen transfer from the environment. The reed bed system was proven to have a good efficiency in removing Biological Oxygen Demand (BOD), Chemical Oxygen Demand (COD), Total Suspended Solid (TSS), Total Dissolve Solid (TDS), Total Nitrogen (TN) and a number of bacteria. In addition to the oxygen transfer from the environment, the interaction among pollutant-plants-medium-microbes also plays a vital role in the removal of pollutant using the reed bed system. It was suggested that the future related research should accommodate the importance of several environmental conditions to the interaction between pollutant, plants, medium and microbes as well as the impact of those interactions on the pollutant removal efficiency.
\end{abstract}

Keywords: domestic wastewater, green technology, interactions, local plants, phytoremediation.

\section{INTRODUCTION}

Phytoremediation is one of the treatment technologies that utilize plants to remediate the pollutants in contaminated environments (Ismail et al., 2017; Purwanti et al., 2019). It improves the condition of environments following the removal of the contamination (Bolan et al., 2011). This technology is also considered to be low cost and environmentally friendly in terms of the real implantation (Kinidi and Salleh, 2017; Tien et al., 2018). The reed bed system is a man-made wetland planted with selected species of plants (reeds) which have a capability to take oxygen from the air and release it into the rhizosphere (Manios et al., 2002). As a result of this action, a very high population of micro-organisms is promoted and enhanced in the rhizosphere (Bolan et al., 2011; Safronova et al., 2006; Titah et al., 2018). The reed bed system is a combination of three interdependent key elements: the growing medium, the plants and the micro-organisms (Ismail et al., 2019; Manios et al., 2002; Zhang et al., 2013).

It is necessary to find the optimal reed bed design characteristics such as residence time in order to maximize the removal efficiency under the smallest-as-possible treatment area (Purwanti et al., 2018b). Understanding the behavior of reed beds treating wastewater is required to obtain the optimum condition for wastewater treatment 
processes. Typically, the domestic wastewater contains pathogens (bacteria), total solids (dissolve and suspended), nutrients (nitrogen and phosphorus), other organic pollutants and traces of heavy metals (Ahmad et al., 2016; Mtshali et al., 2014; Ning et al., 2017; Samer, 2015).

It was reported that up to $18 \%$ of rivers were polluted by organic compounds as the presence of high biochemical oxygen demand (BOD). Around $24 \%$ of rivers in Malaysia were also polluted by ammoniacal nitrogen $\left(\mathrm{NH}_{3}-\mathrm{N}\right)$ originated from sewage that may include the livestock farming activities and domestic wastewater (Katayon et al., 2008; Ministry of Science Technology and the Environment Malaysia, 2003). These pollutants need to be brought down to permissible limits before the disposal of effluent by maximizing removal of pollutants from domestic wastewater (Manju et al., 1998; Tangahu et al., 2019; Titah et al., 2019). Hence, this paper was aimed at discussing about the design of reed bed system for treatment of domestic wastewater. Additionally, the paper also aimed at investigating the effectiveness of native plants in treating domestic wastewater. The result of this study may provide a general design of a phytoremediation reactor, especially using a reed bed system and provide an alternative technology for treating the domestic wastewater.

\section{Design of Reed Bed System}

Figure 1 presents a schematic diagram for the reed bed system, which was designed for the domestic wastewater treatments. It consisted of four lines; each line has three identical beds made of fiberglass columns of $2 \mathrm{~m}$ length, $1 \mathrm{~m}$ width and $1 \mathrm{~m}$ height. The type of medium used for this reed beds mostly consists of gravel of different size and sand. The gravel of different size was employed as a medium in the system with an alternative arrangement $(10-15 \mathrm{~mm}, 3-5 \mathrm{~mm}$ (river sand) and $30-35 \mathrm{~mm}$ respectively) instead of the conventional medium arrangement to form multiple layers in the reed beds (Figure 2).

This bed system was designed to provide oxygen on the surfaces in which other organisms can grow and proliferate. The beds were planted with treatment plants which are highly suggested to be native plants already proven to have good capability in removing pollutants (Imron et al., 2019; Ismail et al., 2015; Purwanti et al., 2018b). Numerous flow systems inside the reed bed, including free flow, subsurface flow (horizontal or vertical flow) or combination of these, can be considered for application (Cossu et al., 2001; Mehraban et al., 2008) and the selection of appropriate flow diagram must consider the characteristic of the wastewater and the type of the used plants (Bolan et al., 2011; Shagol et al., 2011; Tangahu et al., 2011). The reed bed system must be operated in parallel during the operation period to overcome the maintenance time (Dodane et al., 2012).

The availability of oxygen in the reed bed matrix mostly is key factor restricting the removal rates of pollutants (Ahmad et al., 2017; Cossu et al., 2001; Darajeh et al., 2014). Therefore, employing good natural recirculation system may influence the performance of a reed bed by increasing the atmospheric oxygen exchange. Recirculation of wastewater may also be installed in order to enable better diffusion of oxygen from the air to maintain aerobic conditions and also enhance the pollutants-plants-microorganisms interaction (Al-Baldawi et al., 2018; Hasan et al., 2016; Hussain et al., 2018; Kumar and Gopal, 2015; Safronova et al., 2006).

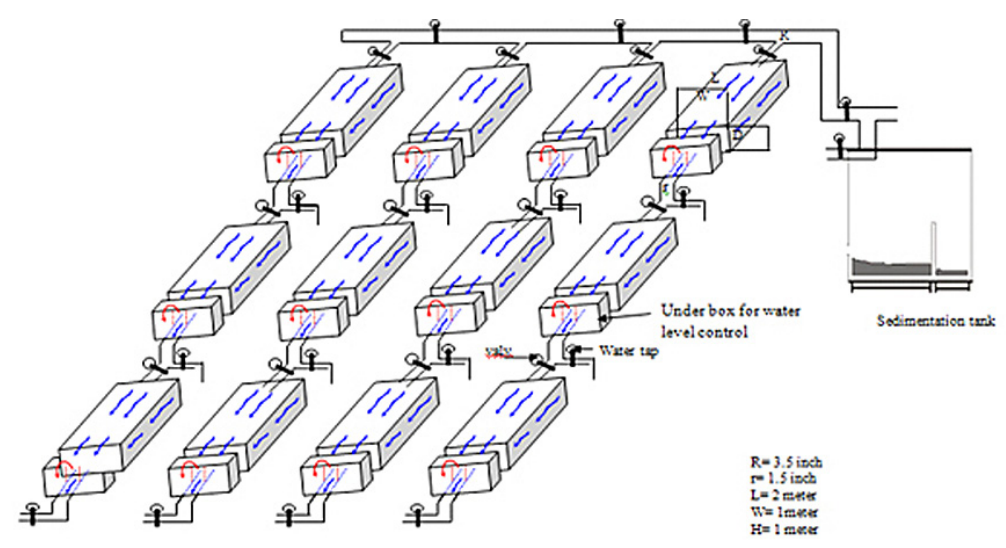

Figure 1. Schematic diagram for the reed bed system 


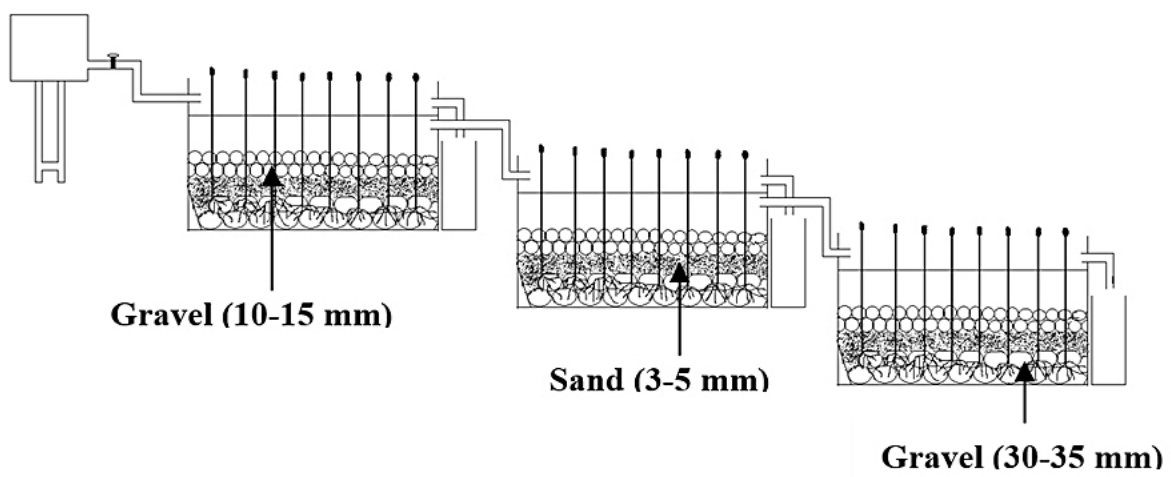

Figure 2. Medium arrangement in this reed bed system

Table 1. Performance of reed bed in treating wastewater

\begin{tabular}{|c|c|c|c|c|c|}
\hline No & Reed bed system & $\begin{array}{l}\text { Type of } \\
\text { effluent }\end{array}$ & Plant species & Findings & Source \\
\hline 1 & $\begin{array}{l}\text { Constructed wetland } \\
\text { system }\end{array}$ & Blackwater & $\begin{array}{c}\text { Vetiveria zizanioi- } \\
\text { des and } \\
\text { Typha angustifolia }\end{array}$ & $\begin{array}{l}\text { A reliable performance to reduce BOD } \\
\text { and COD of blackwater up to the per- } \\
\text { missible value with } 50 \% \text { and } 56 \% \text { of } \\
\text { total removal, respectively. }\end{array}$ & $\begin{array}{l}\text { Wulandari et al. } \\
\qquad(2019)\end{array}$ \\
\hline 2 & $\begin{array}{l}\text { Constructed wetland } \\
\text { system }\end{array}$ & $\begin{array}{l}\text { Food industry } \\
\text { effluent }\end{array}$ & $\begin{array}{c}\text { Scirpus grossus } \\
\text { and } \\
\text { Typha angustifolia }\end{array}$ & $\begin{array}{l}\text { The complete treatment plant con- } \\
\text { sisted of anaerobic baffled reactor } \\
\text { and constructed wetland showed re- } \\
\text { moval of COD, BOD and nutrient up to } \\
99.71 \%, 99.76 \% \text {, and } 98.9 \% \text {, respec- } \\
\text { tively. }\end{array}$ & $\begin{array}{l}\text { Purwanti et al. } \\
\qquad(2018 b)\end{array}$ \\
\hline 3 & $\begin{array}{l}\text { Continuous effluent } \\
\text { recirculation system }\end{array}$ & $\begin{array}{l}\text { High strength } \\
\text { domestic } \\
\text { wastewater }\end{array}$ & $\begin{array}{l}\text { Phragmites } \\
\text { australis }\end{array}$ & $\begin{array}{l}\text { The system achieved total removal } \\
\text { of } 77 \% \text { for } \mathrm{COD}, 78 \% \text { for } \mathrm{BOD}_{5}, 66 \% \\
\text { for suspended solid, } 62 \% \text { for } \mathrm{NH}_{4}-\mathrm{N} \text {, } \\
\text { and } 38 \% \text { for phosphorus, which mean } \\
\text { that effluent recirculation can be con- } \\
\text { sidered to be applied to improve the } \\
\text { removal efficiency of reed bed by en- } \\
\text { hancing interactions between waste- } \\
\text { water, plants, and microorganisms ei- } \\
\text { ther on surface of the medium or in the } \\
\text { rhizosphere. }\end{array}$ & Zhao et al. (2004) \\
\hline 4 & $\begin{array}{l}\text { Conventional and } \\
\text { alternative medium } \\
\text { arrangement system }\end{array}$ & $\begin{array}{l}\text { Farm waste- } \\
\text { water }\end{array}$ & $\begin{array}{l}\text { Phragmites } \\
\text { australis }\end{array}$ & $\begin{array}{l}\text { Considerable removal of } C O D \text { and } \\
B O D_{5} \text { was obtained in both systems. } \\
\text { The total removal percentages of COD } \\
\text { reaching up to } 74.79 \% \text { and } \mathrm{BOD}_{5} \text { up to } \\
67.71 \% \text { in the anti-sized system. These } \\
\text { removal efficiencies were slightly high- } \\
\text { er compared to the progressively-sized } \\
\text { system which only reach } 71.71 \% \text { for } \\
\text { COD and } 66.71 \% \text { for } \mathrm{BOD}_{5} .\end{array}$ & Sun et al. (2007) \\
\hline 5 & Recirculated system & $\begin{array}{l}\text { Farm waste- } \\
\text { water }\end{array}$ & $\begin{array}{l}\text { Cyperus } \\
\text { flabelliforis }\end{array}$ & $\begin{array}{l}\text { Recirculation enhances oxygen trans- } \\
\text { port by pumping and re-distributing the } \\
\text { wastewater and increase its contact } \\
\text { with air. The increasing contact be- } \\
\text { tween wastewater and air will enhance } \\
\text { the respiration and activities of the aer- } \\
\text { obic microorganisms. It also increased } \\
\text { the removal of total nitrogen from } 71 \% \\
\text { to } 85 \% \text { and achieving final COD and } \\
\text { TKN removal of } 95 \% \text { and } 98 \% \text {, respec- } \\
\text { tively. }\end{array}$ & $\begin{array}{l}\text { Kantawanichkul } \\
\text { et al. (2001) }\end{array}$ \\
\hline 6 & Sub-surface system & $\begin{array}{c}\text { Domestic } \\
\text { wastewater }\end{array}$ & Typha latifolia & $\begin{array}{l}\text { Constant removal of } \mathrm{NH}_{3}-\mathrm{N} \text {, reaching } \\
\text { the value up to more than } 80 \% \text {. }\end{array}$ & $\begin{array}{l}\text { Manios et al. } \\
(2002)\end{array}$ \\
\hline 7 & Sub-surface system & $\begin{array}{l}\text { Domestic } \\
\text { wastewater }\end{array}$ & $\begin{array}{l}\text { Lepironia } \\
\text { articulata }\end{array}$ & $\begin{array}{l}\text { A total removal of COD, TSS and total } \\
\text { coliform up to } 77 \%, 88 \% \text {, and } 99 \% \text {, re- } \\
\text { spectively, indicating that sub-surface } \\
\text { system may also handle the high num- } \\
\text { ber of bacteria in wastewater. }\end{array}$ & $\begin{array}{l}\text { Katayon et al. } \\
\qquad(2008)\end{array}$ \\
\hline
\end{tabular}




\section{Reed bed performance and selection of plants}

The performance of reed bed in treating the domestic wastewater is remarkably good. The presented design might provide a better removal efficiency of some parameters in domestic wastewater by providing a better natural oxygen transfer. For additional reference, some studies mention the removal efficiency of the reed bed in treating wastewater, as tabulated oinn Table 1.

In addition to the reed bed system, the capability of the plants used is a non-separated contribution to the overall reed bed performance (Manios et al., 2002; Reed and Glick, 2005; Zhang et al., 2013). It is highly suggested that the involved plants should be native to the location, because it has a better adaptability to the surrounding environmental condition (Abdullah et al., 2020). Since this design will be applied in Malaysia, some Asian native plant species which had been proven to have a good capability in treating wastewater are summarized in Table 2 .

\section{Future research approaches}

Further research in the reed bed topic may analyze the optimum environmental condition during the treatment period. The optimum environmental condition may include retention time (Koottatep and Polprasert, 1997), pH (Dakora and Phillips, 2002), temperature (Vlaev et al., 2011), and the flow system (Cossu et al., 2001; Yasmin et al., 2016). The analysis of the environmental condition is highly suggested to consider the interaction of plant-medium and also plantmicrobes during the reed bed treatment. The highest removal of pollutant is considered to be obtained by achieving the optimum condition for medium-plant-microbes interaction.

\section{CONCLUSIONS}

Reed bed is proven to be highly reliable in treating wastewater, especially from the domestic source. A good reed bed design will give a better chance to

Table 2. Performance of the native Asian plants involved in reed bed system in treating wastewater

\begin{tabular}{|c|c|c|c|c|c|}
\hline No & Plant species & $\begin{array}{l}\text { Type of } \\
\text { plant }\end{array}$ & Location & Summary & Source \\
\hline 1 & Azolla pinnata & Aquatic & Malaysia & $\begin{array}{l}\text { A. pinnata showing a very reliable removal of } \\
\text { COD up to } 100 \% \text { from the pulp and paper indus- } \\
\text { try with the initial concentration of } 72.4 \mathrm{mg} / \mathrm{L} \text {. }\end{array}$ & Ahmad et al. (2017) \\
\hline 2 & Chara vulgaris & Aquatic & India & $\begin{array}{l}\text { Maximum removal of Total Dissolve Solid, COD, } \\
\text { BOD, and electro conductivity of } 68 \%, 78 \%, 82 \% \\
\text { and } 86 \% \text {, respectively were obtained in the } 10 \% \\
\text { of textile effluent concentration after } 120 \text { h of } \\
\text { treatment using C. vulgaris. }\end{array}$ & Mahajan et al. (2019) \\
\hline 3 & $\begin{array}{l}\text { Cyperus fla- } \\
\text { belliforis }\end{array}$ & Terrestrial & Thailand & $\begin{array}{l}\text { The involvement of C. flabelliforis under vertical } \\
\text { recirculated vegetated bed showed a good re- } \\
\text { moval efficiency of total nitrogen, COD and TKN } \\
\text { up to } 85 \%, 95 \% \text { and } 98 \% \text {, respectively. }\end{array}$ & $\begin{array}{c}\text { Kantawanichkul et al. } \\
\text { (2001) }\end{array}$ \\
\hline 4 & $\begin{array}{l}\text { Cyperus ro- } \\
\text { tundus }\end{array}$ & Terrestrial & Indonesia & $\begin{array}{l}\text { C. rotundus having high tolerance to the BOD } \\
\text { content in wastewater up to } 7,500 \mathrm{mg} / \mathrm{L} \text {. This } \\
\text { species can grow well under high organic stress } \\
\text { originated from industrial wastewater. }\end{array}$ & Purwanti et al. (2018a) \\
\hline 5 & Lemna minor & Aquatic & $\begin{array}{l}\text { Malaysia and } \\
\text { Indonesia }\end{array}$ & $\begin{array}{l}\text { L. minor showed a good capability in transferring } \\
\text { oxygen to water, which result in a better pollutant } \\
\text { oxidation and showing a removal efficiency of } \\
\mathrm{NH}_{4}-\mathrm{N} \text { up to } 91 \% \text {. }\end{array}$ & Cossu et al. (2001) \\
\hline 6 & $\begin{array}{l}\text { Lepironia } \\
\text { articulata }\end{array}$ & Terrestrial & Malaysia & $\begin{array}{l}\text { Constructed wetlands planted with } L \text {. articulata } \\
\text { successfully removed Total Suspended Solid } \\
(50.18-88.49 \%), \text { COD }(56.77-77.62 \%), \text { Phospho- } \\
\text { rus }(15.99-88.68 \%), \mathrm{NH}_{4}^{+}(27.50-96.34 \%) \text {, and } \\
\text { total coliforms }(99 \%) \text {. This plant also showed a } \\
\text { capability in removing Total Coli up to } 86 \% \text {. }\end{array}$ & $\begin{array}{l}\text { Katayon et al. (2008); } \\
\text { Yasmin et al. (2016) }\end{array}$ \\
\hline 7 & $\begin{array}{l}\text { Salvinia mo- } \\
\text { lesta }\end{array}$ & Aquatic & Malaysia & $\begin{array}{l}\text { This species showed a total removal of } 100 \% \\
\text { COD from the wastewater of pulp and paper } \\
\text { industry. }\end{array}$ & Ahmad et al. (2017) \\
\hline 8 & $\begin{array}{l}\text { Scirpus gros- } \\
\text { sus }\end{array}$ & Terrestrial & $\begin{array}{l}\text { Malaysia and } \\
\text { Indonesia }\end{array}$ & $\begin{array}{l}\text { Constructed wetland planted with S. grossus } \\
\text { showed a good performance in removing nutri- } \\
\text { ent and fecal coliform bacteria. This plant also } \\
\text { showed good capability in tolerating high COD } \\
\text { content wastewater up to } 7,500 \mathrm{mg} / \mathrm{L} \text {. }\end{array}$ & $\begin{array}{c}\text { Purwanti et al. } \\
(2018 a) ; \text { Tanaka et al. } \\
(2006)\end{array}$ \\
\hline
\end{tabular}


achieve higher removal efficiency of pollutants by providing higher natural oxygen exchange. The application of reed bed treatment was shown to have a capability in removing TSS, COD, BOD, Total Nitrogen, TKN and also bacteria. The performance of reed bed in removing pollutants cannot be separated from the capability of the involved plants species. The interaction between pollutant, medium, plants and also microbes plays an important role in treating wastewater using the reed bed system.

\section{Acknowledgment}

All authors would like to deliver greatest gratitude to Universiti Kebangsaan Malaysia under DCP-2018-006/3 research grant for sponsoring this publication.

\section{REFERENCES}

1. Abdullah, S.R.S., Al-Baldawi, I.A., Almansoory, A.F., Purwanti, I.F., Al-Sbani, N.H., Sharuddin, S.S.N., 2020. Plant-assisted remediation of hydrocarbons in water and soil: Application, mechanisms, challenges and opportunities. Chemosphere. https:// doi.org/10.1016/j.chemosphere.2020.125932

2. Ahmad, J., Abdullah, S.R.S., Hassan, H.A., Rahman, R.A.A., Idris, M., 2017. Screening of tropical native aquatic plants for polishing pulp and paper mill final effluent. Malaysian J. Anal. Sci. 21, 105112. https://doi.org/10.17576/mjas-2017-2101-12

3. Ahmad, T., Ahmad, K., Alam, M., 2016. Sustainable management of water treatment sludge through 3'R' concept. J. Clean. Prod. 124, 1-13. https://doi. org/10.1016/j.jclepro.2016.02.073

4. Al-Baldawi, I.A., Abdullah, S.R.S., Anuar, N., Hasan, H.A., 2018. Phytotransformation of methylene blue from water using aquatic plant (Azolla pinnata). Environ. Technol. Innov. 11, 15-22. https://doi.org/10.1016/j.eti.2018.03.009

5. Bolan, N.S., Park, J.H., Robinson, B., Naidu, R., Huh, K.Y., 2011. Phytostabilization. A green approach to contaminant containment. Adv. Agron. 112, 145-204. https://doi.org/10.1016/ B978-0-12-385538-1.00004-4

6. Cossu, R., Haarstad, K., Lavagnolo, M.C., Littarru, P., 2001. Removal of municipal solid waste COD and NH4-N by phyto-reduction: A laboratory-scale comparison of terrestrial and aquatic species at different organic loads. Ecol. Eng. 16, 459-470. https:// doi.org/10.1016/S0925-8574(00)00106-3

7. Dakora, F.D., Phillips, D.A., 2002. Root exudates as mediators of mineral acquisition in low-nutrient environments. Plant Soil 245, 35-47. https://doi.
org/10.1023/A:1020809400075

8. Darajeh, N., Idris, A., Truong, P., Abdul Aziz,A., Abu Bakar, R., Che Man, H., 2014. Phytoremediation potential of Vetiver system technology for improving the quality of palm oil mill effluent. Adv. Mater. Sci. Eng. 2014. https://doi.org/10.1155/2014/683579

9. Dodane, P.H., Mbéguéré, M., Sow, O., Strande, L., 2012. Capital and operating costs of full-scale fecal sludge management and wastewater treatment systems in Dakar, Senegal. Environ. Sci. Technol. 46, 3705-3711. https://doi.org/10.1021/es2045234

10. Hasan, H.A., Abdullah, S.R.S., Kofli, N.T., Yeoh, S.J., 2016. Interaction of environmental factors on simultaneous biosorption of lead and manganese ions by locally isolated Bacillus cereus. J. Ind. Eng. Chem. 37, 295-305. https://doi.org/10.1016/j. jiec.2016.03.038

11. Hussain, F., Mustufa, G., Zia, R., Faiq, A., Matloob, M., Rehman Shah, H. ur, Rafique Ali, W., Irfan, J.A., 2018. Constructed Wetlands and their Role in Remediation of Industrial Effluents via Plant-Microbe Interaction - A Mini Review. J. Bioremediation Biodegrad. 09. https://doi. org/10.4172/2155-6199.1000447

12. Imron, M.F., Kurniawan, S.B., Soegianto, A., Wahyudianto, F.E., 2019. Phytoremediation of methylene blue using duckweed (Lemna minor). Heliyon 5, e02206. https://doi.org/10.1016/j.heliyon.2019. e02206

13. Ismail, N. 'Izzati, Abdullah, S.R.S., Idris, M., Hasan, H.A., Halmi, M.I.E., Al Sbani, N.H., Jehawi, O.H., 2019. Simultaneous bioaccumulation and translocation of iron and aluminium from mining wastewater by Scirpus grossus. Desalin. Water Treat. 163, 133-142. https://doi.org/10.5004/dwt.2019.24201

14. Ismail, N. 'Izzati, Halmi, M.I.E., AL Sbani, N.H., Idris, M., Hasan, H.A., Hashim, M.H., Abdullah, S.R.S., Jehawi, O.H., Sanusi, S.N.A., Sheikh Abdullah, S.R., Idris, M., Abu Hasan, H., Halmi, M.I.E., Hussin AL Sbani, N., Hamed Jehawi, O., Sanusi, S.N.A., Hashim, M.H., 2017. Accumulation of Fe$\mathrm{Al}$ by Scirpus grossus grown in synthetic bauxite mining wastewater and identification of resistant rhizobacteria. Environ. Eng. Sci. 34, 367-375. https://doi.org/10.1089/ees.2016.0290

15. Ismail, N.I., Sheikh Abdullah, S.R., Idris, M., Hasan, H.A., Al Sbani, N.H., Jehawi, O.H., 2015. Tolerance and survival of scirpus grossus and lepironia articulata in synthetic mining wastewater. J. Environ. Sci. Technol. 8, 232-237. https://doi. org/10.3923/jest.2015.232.237

16. Kantawanichkul, S., Neamkam, P., Shutes, R.B.E., 2001. Nitrogen removal in a combined system: Vertical vegetated bed over horizontal flow sand bed, in: Water Science and Technology. https://doi. org/10.2166/wst.2001.0820 
17. Katayon, S., Fiona, Z., Noor, M.J.M.M., Halim, G.A., Ahmad, J., 2008. Treatment of mild domestic wastewater using subsurface constructed wetlands in Malaysia. Int. J. Environ. Stud. https://doi. org/10.1080/00207230601125192

18. Kinidi, L., Salleh, S., 2017. Phytoremediation of Nitrogen as Green Chemistry for Wastewater Treatment System. Int. J. Chem. Eng. 2017. https://doi. org/10.1155/2017/1961205

19. Koottatep, T., Polprasert, C., 1997. Role of plant uptake on nitrogen removal in constructed wetlands located in the tropics. Water Sci. Technol. 36, 1-8. https://doi.org/10.1016/S0273-1223(97)00725-7

20. Kumar, B.L., Gopal, D.V.R.S.R.S., 2015. Effective role of indigenous microorganisms for sustainable environment. 3 Biotech 5, 867-876. https://doi. org/10.1007/s13205-015-0293-6

21. Mahajan, P., Kaushal, J., Upmanyu, A., Bhatti, J., 2019. Assessment of Phytoremediation Potential of Chara vulgaris to Treat Toxic Pollutants of Textile Effluent. J. Toxicol. 2019. https://doi. org/10.1155/2019/8351272

22. Manios, T., Stentiford, E.I., Millner, P.A., 2002. The removal of NH3-N from primary treated wastewater in subsurface reed beds using different substrates. J. Environ. Sci. Heal. - Part A Toxic/Hazardous Subst. Environ. Eng. 37, 297-308. https://doi.org/10.1081/ ESE-120002829

23. Manju, G.N., Raji, C., Anirudhan, T.S., 1998. Evaluation of coconut husk carbon for the removal of arsenic from water. Water Res. https://doi.org/10.1016/ S0043-1354(98)00068-2

24. Mehraban, P., Zadeh, A.A., Sadeghipour, H.R., 2008. Iron toxicity in rice (Oryza sativa L.), under different potassium nutrition. Asian J. Plant Sci. 7, 251-259. https://doi.org/10.3923/ajps.2008.251.259

25. Ministry of Science Technology and the Environment Malaysia, 2003. Environmental Quality Report.

26. Mtshali, J.S., Tiruneh, A.T., Fadiran, A.O., 2014. Sewage sludge, Nutrient value, Organic fertilizer, Soil amendment, Sludge reuse, Nitrogen, Phosphorus; Sewage sludge, Nutrient value, Organic fertilizer, Soil amendment, Sludge reuse, Nitrogen, Phosphorus. Resour. Environ. 4, 190-199. https:// doi.org/10.5923/j.re.20140404.02

27. Ning, Y.-F., Dong, W.-Y., Lin, L.-S., Zhang, Q., 2017. Current research trend on urban sewerage system in China. IOP Conf. Ser. Earth Environ. Sci. 59, 012048. https://doi.org/10.1088/1755-13 $15 / 59 / 1 / 012048$

28. Purwanti, I.F., Simamora, D., Kurniawan, S.B., 2018a. Toxicity test of tempe industrial wastewater on cyperus rotundus and scirpus grossus. Int. J. Civ. Eng. Technol. 9, 1162-1172.
29. Purwanti, I.F., Tangahu, B.V., Titah, H.S., Kurniawan, S.B., 2019. Phytotoxicity of aluminium contaminated soil to scirpus grossus and typha angustifolia. Ecol. Environ. Conserv. 25, 523-526.

30. Purwanti, I.F., Titah, H.S., Tangahu, B.V., Kurniawan, S.B., 2018b. Design and application of wastewater treatment plant for "pempek" food industry, Surabaya, Indonesia. Int. J. Civ. Eng. Technol. 9, 1751-1765.

31. Reed, M.L.E., Glick, B.R., 2005. Growth of canola (Brassica napus) in the presence of plant growthpromoting bacteria and either copper or polycyclic aromatic hydrocarbons. Can. J. Microbiol. https:// doi.org/10.1139/w05-094

32. Safronova, V.I., Stepanok, V. V., Engqvist, G.L., Alekseyev, Y. V., Belimov, A.A., 2006. Root-associated bacteria containing 1-aminocyclopropane1-carboxylate deaminase improve growth and nutrient uptake by pea genotypes cultivated in cadmium supplemented soil. Biol. Fertil. Soils. https://doi. org/10.1007/s00374-005-0024-y

33. Samer, M., 2015. Biological and Chemical Wastewater Treatment Processes, in: Wastewater Treatment Engineering. InTech. https://doi.org/10.5772/61250

34. Shagol, C.C., Chauhan, P.S., Kim, K.-Y., Lee, S.-M., Chung, J.-B., Park, K.-W., Sa, T.-M., 2011. Exploring the Potential of Bacteria-Assisted Phytoremediation of Arsenic-Contaminated Soils. Korean J. Soil Sci. Fertil. 44, 58-66. https://doi.org/10.7745/ kjssf.2011.44.1.058

35. Sun, G., Zhao, Y.Q., Allen, S.J., 2007. An alternative arrangement of gravel media in tidal flow reed beds treating pig farm wastewater. Water. Air. Soil Pollut. https://doi.org/10.1007/s11270-006-9316-6

36. Tanaka, N., Jinadasa, K.B.S.N., Werellagama, D.R.I.B., Mowjood, M.I.M., Ng, W.J., 2006. Constructed tropical wetlands with integrated submergent-emergent plants for sustainable water quality management. J. Environ. Sci. Heal. - Part A Toxic/Hazardous Subst. Environ. Eng. https://doi. org/10.1080/10934520600867581

37. Tangahu, B.V., Ningsih, D.A., Kurniawan, S.B., Imron, M.F., 2019. Study of BOD and COD Removal in Batik Wastewater using Scirpus grossus and Iris pseudacorus with Intermittent Exposure System. J. Ecol. Eng. 20, 130-134. https://doi. org/10.12911/22998993/105357

38. Tangahu, B.V., Sheikh Abdullah, S.R., Basri, H., Idris, M., Anuar, N., Mukhlisin, M., 2011. A review on heavy metals ( $\mathrm{As}, \mathrm{Pb}$, and $\mathrm{Hg}$ ) uptake by plants through phytoremediation. Int. J. Chem. Eng. 2011, 1-31. https://doi.org/10.1155/2011/939161

39. Tien, W.T.H., Tan, I.A.W., Salleh, S.F., Wahab, N.A., 2018. Phytoremediation of ammoniacal nitrogen in wastewater using Eichhornia crassipes: Tolerance limit and pH study. Malaysian Appl. Biol. 
40. Titah, H.S., Purwanti, I.F., Tangahu, B.V., Kurniawan, S.B., Imron, M.F., Abdullah, S.R.S., Ismail, N. 'Izzati, 2019. Kinetics of aluminium removal by locally isolated Brochothrix thermosphacta and Vibrio alginolyticus. Journal of Environmental Manaement, 238, 194-200. https://doi.org/10.1016/j. jenvman.2019.03.011

41. Titah, H.S., Rozaimah, S., Abdullah, S.R.S., Idris, M., Anuar, N., Basri, H., Mukhlisin, M., Tangahu, B.V., Purwanti, I.F., Kurniawan, S.B., 2018. Arsenic resistance and biosorption by isolated Rhizobacteria from the roots of Ludwigia octovalvis. Int. J. Microbiol. 2018, 1-10. https://doi. org/10.1155/2018/3101498

42. Vlaev, L., Petkov, P., Dimitrov, A., Genieva, S., 2011. Cleanup of water polluted with crude oil or diesel fuel using rice husks ash. J. Taiwan Inst. Chem. Eng. 42, 957-964. https://doi.org/10.1016/j. jtice.2011.04.004
43. Wulandari, L.K., Bisri, M., Harisuseno, D., Yuliani, E., 2019. Reduction of BOD and COD of by using stratified filter and constructed wetland for blackwater treatment. IOP Conf. Ser. Mater. Sci. Eng. 469. https://doi.org/10.1088/1757-899X/469/1/012024

44. Yasmin, M.H.A., Idris, M., Abdullah, S.R.S., 2016. Application of plant-based reed for potable water, in Tasik Chini, Pahang. AIP Conf. Proc. 1784. https:// doi.org/10.1063/1.4966870

45. Zhang, X., Wang, Z., Liu, X., Hu, X., Liang, X., Hu, Y., 2013. Degradation of diesel pollutants in Huangpu-Yangtze River estuary wetland using plantmicrobe systems. Int. Biodeterior. Biodegrad. 76, 71-75. https://doi.org/10.1016/j.ibiod.2012.06.017

46. Zhao, Y.Q., Sun, G., Allen, S.J., 2004. Purification capacity of a highly loaded laboratory scale tidal flow reed bed system with effluent recirculation. Sci. Total Environ. https://doi.org/10.1016/j. scitotenv.2004.03.002 